\title{
PEOPLE PERCEPTION AND PARTICIPATION IN DISASTER RISK REDUCTION AT SURAKARTA CITY, CENTRAL JAVA, INDONESIA
}

\author{
Chatarina Muryani ${ }^{1}$, Sorja Koesuma ${ }^{2}$, Yasin Yusup ${ }^{3}$ \\ ${ }^{1,3}$ Geography Education, Universitas Sebelas Maret \\ ${ }^{2}$ Physics Department, Universitas Sebelas Maret \\ Email: chatarinamuryani@ staff.uns.ac.id
}

\begin{abstract}
The research was aimed to determine (1) people knowledge level for the flood risk in Surakarta; (2) people perception of the flood risk in Surakarta; (3) community participation in the flood management in Surakarta. The city of Surakarta was chosen as the research location since this area was commonly flooded in rainy seasons and even in one year there can be floods repeatedly. Data collection methods used was field observation, structured interview and FGD. Data analysis was done by scoring. The results showed that: (1) Surakarta resident knowledge of the flood risk was in the high category. They can independently adapt to the flood disasters that often hit their area; (2) People perceptions of the flood risk disaster were in the high category. This was due to the Early Warning System (EWS) and the Search and rescue (SAR) teams information system which were well managed and easily accessed, (3) People participation in flood disaster management in Surakarta was in the "medium" category. The people participation in funding contributions and community service activities was high. However, the participation in the maintenance of water pumps, floodgates and river embankments was low.
\end{abstract}

Keywords: Floods; Perception; Participation; Community

\section{A. INTRODUCTION}

The occurrence of climate change will affect the abiotic and biotic components on the earth's surface (IPCC, 2012). The affected abiotic components are: air temperature, rainfall, wind pattern, and sea level. The Biotic components influenced are all the populations living on the earth's surface. Global warming has an effect on the the air temperature increase which impacts climate change through changes in the atmospheric circulation and hydrology on the earth. Changes in the hydrological cycle, including rain, are very influential on human life (Manik et al., 2014). Long drought or heavy rain in a short duration that has oftenly occurred since the last few years is closely related to climate deviations due to natural phenomena such as: El Nino, La Nina, Dipole Mode, and global warming (Sipayung, 2009). Very high rainfall intensity in a short time can cause flooding and landslides, or otherwise if there is no rain for a long time it will cause drought (Siregar et al., 2019).

Extreme weather has been experienced since the beginning of human civilization. Beginning with Noah, 
Mesopotamia and Egypt, they had flood stories in their collective mythology. The characteristics, causes, and impacts of the floods all appear to be similar (Mcdonald, 2018). Flood-prone areas often have a mixed factor between the presence of settlements and economic activity (Sinha, 2016). Preassures, such as demographic change, environmental degradation, climate variability, and increased economic and social activity, affect the level of flooding impacts on household and economic activities (WMO, 2012). Therefore, flooding is a major risk in urban areas. The rising risks of climate change and Indonesia's dynamic urban and industrial development has caused several areas to become vulnerable to flood (Putri et al., 2019).

Surakarta City in Central Java Province, which was the research area, is located adjacent to the Bengawan Solo River. Since very ancient times, human settlements were highly established around the river since it was acomodating the mobilization, thereby encouraging cultural organization and fostering economic growth (Nardi et al., 2019). However, living on a floodplain can have disastrous consequences. Watershed conversion can lead to increased annual runoff and peak discharge with consequences on flow volume and thereby inducing flood events (Du et al.,
2012; Prosdocimi et al., 2015; Suriya \& Mudgal, 2012).

People respond and adapt to flood risk for different reasons and with different strategies (Ridolfi et al., 2020). In addition, human action can greatly alter hydrological extremes through implementing flood control or mitigation. For example, embankment and dam systems affect the frequency and magnitude of floods and droughts (Di Baldassarre et al., 2017).

Understanding perceptions of flood risk and the factors that influence it has important social and political implications since the level of awareness of flood risk directly influences community actions before and during floods (Grothmann \& Reusswig, 2006). Key factors affecting risk perception include: (1) previous experience, (2) information provided by the mass media or communication channels and; 3) trust in authority and flood defense measures (Wachinger et al., 2013). In addition, the importance of stakeholder participation in decision making, and in particular flood risk management, has been recognized by international and regional treaties such as the Aarhus Convention, which encourages people participation in decision-making on environmental issues, and the European Flood Directive 2007/60/EC, which requires the 
establishment of a people participation mechanism to ensure citizen involvement in the flood management cycle (Wehn et al., 2015).

The purpose of this study was to determine the people perceptions and participation in reducing the flood risk in the Surakarta. By knowing the perceptions and participation of the community, it can be used for policy making in subsequent flood management.

\section{B. MATERIALS AND METHODS}

\section{Study Area}

The study was conducted in Surakarta since this area was heavily affected by flooding almost every year and causes large economic losses and extensive impacts. The frequent occurrence of floods was due to the location of Surakarta city which is on the outskirts of Bengawan Solo River, which is the longest river on Java Island. The history of flooding in the study area occurred before the city itself was established.

\section{Sample Selection and Data Collecting}

The population was all residents who live in flood-prone areas in Surakarta. Based on the data from BPBD, there are 14 villages lies in flood prone area, there are Semanggi, Sangkrah,
Kedunglumbu, Joyosuran, Kliwon Market (Pasar Kliwon District); Tipes Village, Joyotakan, Serengan (Serengan District); Bumi and Pajang Village (Laweyan District) and Kadipiro Village (Banjarsari District).

Sampling method used was cluster sampling method. From each highly disaster prone village, one cluster was selected, and from each cluster, 10 families were selected as the respondents. Thus, there are $10 \times 14=140$ respondents. Each respondent was interviewed directly using the interview guidelines prepared.

\section{Data Analysis}

1) Knowledge Level Analysis

The level of people knowledge on the flood risk in Surakarta was analyzed from questionnaire responses distributed inline with the survey on people perceptions and participation. There are 5 questions related to knowledge, there are knowledge of threats, flooding factors, Early Warning Systems (EWS), location of evacuation and stakeholder to be contacted. The answer option score is $5,4,2,1$. The maximum score obtained is $5 \times 5 \times 140$ $=3500$ and the minimum score is $1 \times 5 \times 140=700$. The classifications for people knowledge are: 
Table 1. Classifications for People Knowledge

\begin{tabular}{cc}
\hline Knowledge & Score \\
\hline $700-1633$ & Low \\
\hline $1634-2566$ & Medium \\
\hline $2567-3500$ & high \\
\hline
\end{tabular}

2) Analysis of people perceptions

The people perception indicator uses the perception indicator from (Wachinger et al., 2013) there are: (1) experience of previous events, (2) information provided by mass media or communication channels and; 3) confidence in the authority and flood defense measures. Each indicator is described in 3 questions so that overall there are 9 questions. The answer option scores are 5, 3, 2 and 1. The maximum score obtained is $5 \times 9 \times 140=6300$ and the minimum score is 1260 . The classifications for perception are:

Table 2. Classifications for The Perception

\begin{tabular}{cc}
\hline Perception & Score \\
\hline $1260-2940$ & Low \\
\hline $2941-4620$ & Medium \\
\hline $4621-6300$ & high \\
\hline
\end{tabular}

3) Analysis of people participation

Participatory processes have been recognized as an essential element of community-based risk management that builds a culture of safety and ensures sustainable development (Murase et al., 2008). In this study there are 3 indicators of participation: (1) in the form of ideas, funds, labor, and tangible or intangible goods, (2) operation of pumps and sluices, and (3) expansion of green open space (Sulistyani, 2016). Each indicator is described in 3 questions so that there are 9 questions. The answer option score is $5,4,2,1$. The maximum score for the respondent's answer is $5 \times 9 \times 140=$ 6300 and the minimum score is $1 \times 9 \times 140=1260$. The classification of community participation is: 
Table 3. Classification of Community Participation

\begin{tabular}{cc}
\hline Participation & Score \\
\hline $1260-2940$ & Low \\
\hline $2941-4620$ & Medium \\
\hline $4621-6300$ & high \\
\hline
\end{tabular}

\section{RESULTS AND DISCUSSION}

\section{People Knowledge of Disaster Risks}

The people knowledge on Disaster Managemant is an important role in reducing disasters impact. It helps people at the decision-making to produce contextual decisions, as these decisions result from the interaction of the social entities and their experiences as well as those in the field to react appropriately to disasters (Inan \& Beydoun, 2017). The people knowledge that living in disasterprone areas is also important because it relates to efforts to save themselves and their assets. The knowledge of the people of Surakarta about the disaster risk is as follows:

Table 4. People Knowledge of Risk

\begin{tabular}{lllllllc}
\hline \multirow{2}{*}{ No } & \multicolumn{1}{c}{ Knowledge } & \multicolumn{5}{c}{ Score } & \multirow{2}{*}{ Total } \\
\cline { 3 - 6 } & & 5 & 4 & 2 & 1 & score \\
\hline 1 & Flood risk & 135 & 5 & - & - & 695 \\
2 & Flood Factors & 87 & 34 & 15 & 4 & 620 \\
3 & Early Warning System (EWS) & 112 & 25 & 3 & - & 605 \\
4 & Evacuation location & 130 & 10 & - & - & 690 \\
5 & Stakeholders to be Contacted & 78 & 13 & 16 & 13 & 503 \\
\hline & Total score & & & & & 3.113 \\
\hline & Category & & & & & High \\
\hline
\end{tabular}

Source: primary data

From the aspect of knowledge, people that living in flood-prone areas in Surakarta city had high knowledge of disaster risks, early warning systems (EWS), evacuation locations and stakeholders who must be contacted if they need assistance in the disaster case. It could be stated that the attention of stake holders and the information system was running well. A high level of 
knowledge will make it easier for the government to increase community disaster resilience.

\section{Perception of flood risk}

The results of interviews regarding public perceptions on flood risk in Surakarta could be presented in the following table.

Table 5. Public Perception to Flood Risk

\begin{tabular}{|c|c|c|c|c|c|c|}
\hline \multirow{2}{*}{ No } & \multirow{2}{*}{ Perception } & \multicolumn{4}{|c|}{ Score } & \multirow{2}{*}{$\begin{array}{l}\text { Total } \\
\text { score }\end{array}$} \\
\hline & & 5 & 4 & 2 & 1 & \\
\hline 1 & Interruption of activity & 200 & 288 & 30 & 13 & 531 \\
\hline 2 & Trauma to floods & 340 & 160 & 56 & 4 & 560 \\
\hline 3 & The vulnerability of the poor & 300 & 96 & 40 & 21 & 457 \\
\hline 4 & Speed of EWS information & 350 & 112 & 56 & 14 & 532 \\
\hline 5 & Evacuation information & 380 & 168 & 30 & 7 & 585 \\
\hline 6 & Logistical support information & 220 & 192 & 74 & 11 & 497 \\
\hline 7 & $\begin{array}{l}\text { Government's role in flood } \\
\text { prevention }\end{array}$ & 350 & 176 & 24 & 14 & 564 \\
\hline 8 & SAR role in rescue & 350 & 168 & 20 & 18 & 556 \\
\hline 9 & $\begin{array}{l}\text { Trust in flood prevention } \\
\text { buildings }\end{array}$ & 260 & 192 & 50 & 15 & 517 \\
\hline & Total score & & & & & 4.799 \\
\hline & category & & & & & High \\
\hline
\end{tabular}

Source: primary data

Floods were considered a common thing for the residents. They did not feel disturbed and remained active even though there were some obstacles. Communities could independently overcome obstacles caused by flooding. Public perceptions of flood management were generally positive since information on the flood approach is quick, the SAR
Team could be relied upon and logistical support could reach the community quickly. The public also trusted the Government in its efforts to manage floods in the Surakarta. However, the community really hoped that floods could be managed better so that their settlements could be free from flood disasters. 
3. Community participation in disaster risk reduction

The most common elements of community involvement are partnership, participation, empowerment and ownership by local communities (Rajeev, 2014). Community participation is considered a key aspect of achieving sustainability in facing the risk of natural disasters (Huq, 2016). The results of interviews regarding community participation in flood disaster risk reduction in Surakarta were as follows:

Table 6. People Participation on Disaster Management

\begin{tabular}{llllllc}
\hline \multirow{2}{*}{ No } & \multicolumn{1}{c}{ Participation } & \multicolumn{4}{c}{ Score } & Total \\
\cline { 3 - 6 } & & 5 & 4 & 2 & 1 & score \\
\hline 1 & Ideas contribution & 130 & 136 & 104 & 28 & 398 \\
2 & Funds contribution & 150 & 212 & 84 & 15 & 461 \\
3 & Labors contribution & 280 & 176 & 62 & 9 & 527 \\
4 & Supervising pump work & 225 & 144 & 72 & 23 & 464 \\
5 & Supervising floodgates works & 160 & 120 & 84 & 36 & 400 \\
6 & Supervising embankment works & 120 & 112 & 92 & 42 & 366 \\
7 & Utilization of river banks & 220 & 240 & 48 & 12 & 520 \\
8 & Participation in planting trees & 275 & 268 & 30 & 3 & 576 \\
9 & Participation in making biopore & 56 & 120 & 96 & 34 & 306 \\
\hline \multirow{2}{*}{} & Total score & & & & & 4018 \\
\hline
\end{tabular}

Source: primary data

Community participation for flood risk reduction in the Surakarta was in the "medium" category. Participation in the form of funds was generally high, but for participation in the form of labor and ideas was medium. Pumps and sluice gates maintenance was carried out by officers and the community did not participate in controlling them. Most people had planted trees as recommended by the Government, but only a few had made biopore in their yard.

\section{CONCLUSIONS}

The Surakarta residents knowledge level on the flood risk was in the 'high' category, they can independently adapt to the flood disasters that often hit their area. 
People perceptions on flood risks in their area were in the 'high' category. This was due to the good information system regarding the Early Warning System, SAR and logistic support. Community participation in flood risk reduction in Surakarta was in the "medium" category. The community participated in funding contributions and community service activities. However, the patricipation on the maintenance of water pumps, floodgates and river embankments was low.

\section{E. ACKNOWLEDGMENTS}

Acknowledgments are addressed to the National Research and Innovation Agency, Ministry of Research and Technology for providing research grants for the Applied Research Grant scheme.

\section{F. REFERENCES}

Di Baldassarre, G., Martinez, F., Kalantari, Z., \& Viglione, A. (2017). Drought and flood in the Anthropocene: Feedback mechanisms in reservoir operation. Earth System Dynamics, 8(1), 225233. https://doi.org/10.5194/esd-8225-2017

Du, J., Qian, L., Rui, H., Zuo, T., Zheng, D., Xu, Y., \& Xu, C. Y. (2012). Assessing the effects of urbanization on annual runoff and flood events using an integrated hydrological modeling system for Qinhuai River basin, China. Journal of Hydrology, 464-465, 127-139. https://doi.org/10.1016/j.jhydrol.20 12.06.057

Grothmann, T., \& Reusswig, F. (2006). People at risk of flooding: Why some residents take precautionary action while others do not. Natural Hazards, 38(1-2), 101-120. https://doi.org/10.1007/s11069005-8604-6

Huq, S. M. S. (2016). Community Based Disaster Management Strategy in Bangladesh: Present Status, Future Prospects and Challenges. European Journal of Research in Social Sciences, 4(2), 22-35.

Inan, D. I., \& Beydoun, G. (2017). Disaster Knowledge Management Analysis Framework Utilizing Agent-Based Models: Design Science Research Approach. Procedia Computer Science, 124, 116-124.

https://doi.org/10.1016/j.procs.201 7.12.137

IPCC. (2012). Managing The Risks of Extreme Events and Disaster to Advance Climate Change Adaption. In Cambridge University Press. Cambridge University Press. https://doi.org/10.1017/CBO97811 39177245.009

Manik, T. K., Rosadi, B., \& Nurhayati, E. (2014). Mengkaji dampak perubahan iklim terhadap distribusi curah hujan lokal di Propinsi Lampung. Forum Geografi, 28(1), 73-86.

Mcdonald, L. A. (2018). Worldwide Waters: Laurasian Flood Myths and Their Connections. Georgia Southern University.

Murase, M., Tyagi, A. C., Saalmueller, J., \& Nagata, T. (2008). ORGANIZING COMMUNITY PARTICIPATION FOR FLOOD MANAGEMENT A Tool for Integrated Flood Management. 
Management, ORGANIZING(March 2008), 1-10. http://www.apfm.info/pdf/ifm_tool s/Tools_Organizing_Community_P articipation_for_FM.pdf

Nardi, F., Annis, A., Baldassarre, G. Di, Vivoni, E. R., \& Grimaldi, S. (2019). GFPLAIN250m, a global high-resolution dataset of earth's floodplains. Scientific Data, 6, 1-6. https://doi.org/10.1038/sdata.2018. 309

Prosdocimi, I., Kjeldsen, T. R., \& Miller, J. D. (2015). Detection and attribution of urbanization effect on flood extremes using nonstationary flood-frequency models. Water Resources Research, 51, 4244 4262. https://doi.org/10.1111/j.17521688.1969.tb04897.x

Putri, I. A. P., Dalimunthe, S. A., \& Prasojo, A. P. S. (2019). The Right to Live Dangerously: Public Perceptions of Extreme Water Events in Urban Areas. 2nd International Conference on Strategic and Global Studies (ICSGS 2018), 365. https://doi.org/10.2991/icsgs18.2019 .5

Rajeev, M. M. (2014). Sustainability and Community Empowerment in Disaster Management. International Journal of Social Work and Human Services Practice, 2(6), 207-212.

Ridolfi, E., Albrecht, F., \& Di Baldassarre, G. (2020). Exploring the role of risk perception in influencing flood losses over time. Hydrological Sciences Journal, 65(1), 12-20. https://doi.org/10.1080/02626667.2 019.1677907

Sinha, A. (2016, November 9). World Meteorological Organisation assessment: 2016 set to be warmest ever. The Indian Express. https://indianexpress.com/article/in dia/india-news-india/climatechange-global-warming-worldmeteorological-organisationassessment-2016-set-to-bewarmest-ever-c4365064/

Sipayung, S. B. (2009). Analisis Variasi Curah Hujan Berdasarkan Zona Prediksi Iklim (ZPI) di Wilayah Subang dan Tasikmalaya Tahun 1980-2005. Majalah Sains Dan Teknologi Dirgantara, 4(2), 67-74.

Siregar, D. C., Kusumah, B. W., \& Ardah, V. P. (2019). Analisis Variabilitas Curah Hujan dan Suhu Udara di Tanjungpinang. Jurnal Material Dan Energi Indonesi, 09(02), 5360.

Sulistyani, D. (2016). Community Participation Helps Government in Flood Disaster Management. Scientific Research Journal (SCIRJ), IV(VIII), 45-48.

Suriya, S., \& Mudgal, B. V. (2012). Impact of urbanization on flooding: The Thirusoolam sub watershed - A case study. Journal of Hydrology, 412-413, 210-219. https://doi.org/10.1016/j.jhydrol.20 11.05.008

Wachinger, G., Renn, O., Begg, C., \& Kuhlicke, C. (2013). The risk perception paradox-implications for governance and communication of natural hazards. Risk Analysis, 33(6), 1049-1065. https://doi.org/10.1111/j.15396924.2012.01942.x

Wehn, U., Rusca, M., Evers, J., \& Lanfranchi, V. (2015). Participation in flood risk management and the potential of citizen observatories: A governance analysis. Environmental Science and Policy, 48 , 225-236. 
https://doi.org/10.1016/j.envsci.201 4.12.017

WMO. (2012). WMO statement on the status of the global climate in 2012. In World Meteorological
Organization (Issue 1108). World Meteorological Organization. http://www.wmo.int/pages/mediace ntre/press_releases/documents/WM O_1108_EN_web_000.pdf 